\title{
Hydrocarbon generation conditions and exploration potential of the Taoudeni Basin, Mauritania
}

\author{
Gang Wenzhe* \\ Key Laboratory of Hydrocarbon Accumulation Mechanism, Ministry of Education, China University of \\ Petroleum, Beijing 102249, China
}

\begin{abstract}
The Taoudeni Basin is a typical and steady intracratonic basin in Mauritania, northwest Africa. There are six sets of potential source rocks and five regional unconformable surfaces of the Infracambrian and Paleozoic developed in the basin. We used seismic stratigraphic correlation to recover the denudation thickness of formations at a particular well location. Studies of the hydrocarbon generation history of the basin illustrate that hydrocarbon migration and accumulation occurred in the end of the Carboniferous, and after that, the whole basin suffered denudation for a long period of time. Because there is no thick Mesozoic overburden in the basin, the Silurian source rocks could not generate hydrocarbon in the Mesozoic era for the second time. Consequently, the prospects for successful hydrocarbon exploration in the basin are not good.
\end{abstract}

Key words: Source rock, burial history, hydrocarbon generation history, hydrocarbon prospect, Taoudeni Basin

\section{Introduction}

The Taoudeni Basin is a poorly explored basin. Early studies showed that the basin had some exploration prospectivity and the Abolag-1 well produced gas at about 13,600 $\mathrm{m}^{3} /$ day. Researchers have studied the Taoudeni Basin, but the focus has not been on the prospectivity for oil and gas (Macgregor et al, 1998; Mann et al, 2003). As a result, the present knowledge cannot provide scientific guidance for further exploration. Generally, for an old basin, if the hydrocarbon generation period is early and the degree of evolution is high, preservation of gas is always difficult. This is due to the characteristics of gas itself. Based on the data available, the basin has good source rocks and reservoir-cap conditions, so the key of the problem is whether gas can be effectively accumulated (USGS, 2000; van de Weerd and Ware, 1994).

\section{Geological background}

The Taoudeni Basin with an area of $1,500,000 \mathrm{~km}^{2}$ is a broad intracratonic basin, which is in the southeast of Mauritania and west of Mali (Underdown and Redfern, 2008). Despite its enormous size, the 2D seismic surveys are only $6,268 \mathrm{~km}$, and a profile of the Mauritania sector of the basin has been acquired. Since 1975, only two wells, Abolag-1 (drilled by Texaco in 1974) and Ouasa-1 (drilled by Agip in 1974) have been drilled, but no exploration has been carried out in the basin. A production sharing contract (PSC) for blocks Ta13 and Ta21 was signed between

*Corresponding author. email: gwz@cup.edu.cn

Received July 3, 2008
CNPC International Ltd. (assigned to CNPC International (Mauritania) Ltd. on March 25, 2005) and the Islamic Republic of Mauritania on September 6, 2004. The contract took effect on January 23, 2005 for performing hydrocarbon exploration and development in the two blocks, which cover an area of $35,700 \mathrm{~km}^{2}$ (Fig. 1) (Tong and Guan, 2002) and the initial exploration period is three years.

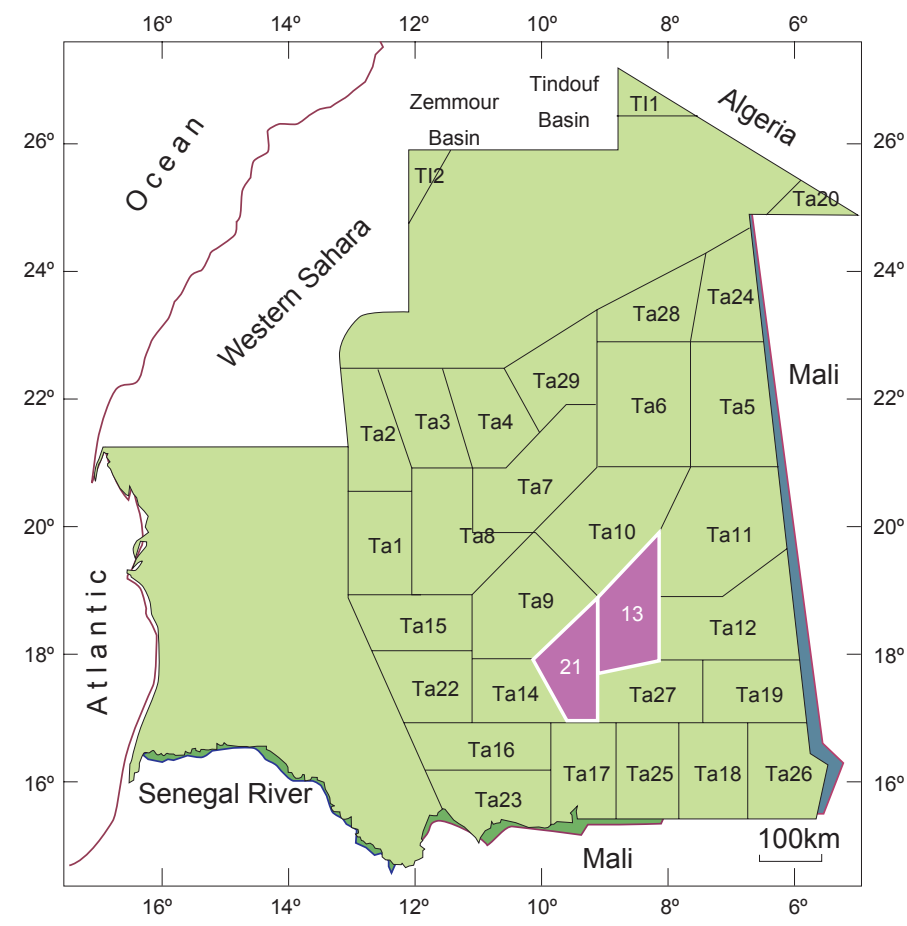

Fig. 1 Location map of Ta13 and Ta21 blocks in the Taoudeni Basin 


\section{Distribution and geochemical characteristics of source rocks}

The Taoudeni Basin is a typical and steady intracratonic basin. Its source rocks have similar characteristics, but their thickness varies from 20 to $500 \mathrm{~m}$. From bottom to top, there are six sets of potential source rocks developed in the whole basin: the lower Infracambrian, middle Infracambrian, upper Infracambrian, Cambrian, Silurian and Devonian. The organic matter abundance of source rocks in different strata varies significantly (Arthur et al, 2003; Bennett et al, 2005). The kerogens are of sapropelic marine facies type II.

At the moment, there are only a little well data in the Taoudeni Basin. The wells Abolag-1 and Ouasa-1 are the only two coring wells drilled in the Mauritania sector of the basin. The features shown by the two wells are unable to truly reflect the source rock distribution within the entire Taoudeni Basin. Source rock intervals in the two wells consist of red mudstone, grayish-brown mudstone and black mudstone. There are two periods of the development of large-scale depressions in the Taoudeni Basin, which are the Infracambrian and Paleozoic depression development periods.
During the Infracambrian, two depressions were developed: the Maqteir Depression in the east and the Taoudeni Depression in the west. The Paleozoic depressions were superimposed upon the Infracambrian structural settings.

Infracambrian source rocks are mainly distributed in the Maqteir and Taoudeni Depressions. The Taoudeni Depression is located in Mali, which covers a large area and is buried to a great depth. The Maqteir Depression is located in Mauritania and it covers an area much smaller than the Taoudeni Depression. Paleozoic source rocks are mainly distributed in the Paleozoic depressions.

Based on the interpretation of regional seismic data and the characteristics of mudstone distribution of the two wells, we constructed source rock distribution maps in the upper and middle Infracambrian (Fig. 2 and Fig. 3). The drilling cuttings from the depth of $8,865-9,425 \mathrm{ft}$ in the Abolag- 1 well have a TOC value of up to $2.65 \%$ (for mudstone). TOC in Ouasa-1 well is less than $1 \%$. Silurian source rocks are mainly distributed in the Taoudeni Depression (Huang et al, 2003). Their thickness exceeds a hundred meters within the depression, but varies significantly outside the depression due to uplift and denudation. The TOC contents for different intervals are listed in Table 1.

Table 1 Contents of organic carbon in mudstones of different strata

\begin{tabular}{ccccc}
\hline Stratum & Devonian & Upper Ordovician & $\begin{array}{c}\text { Cambrian- } \\
\text { Ordovician }\end{array}$ & Infracambrian \\
\hline TOC $\%$ & 0.39 & $0.05-0.07$ & 0.02 & $\begin{array}{c}0.03-0.95 \\
\text { (maximum 2.65) }\end{array}$ \\
\hline
\end{tabular}

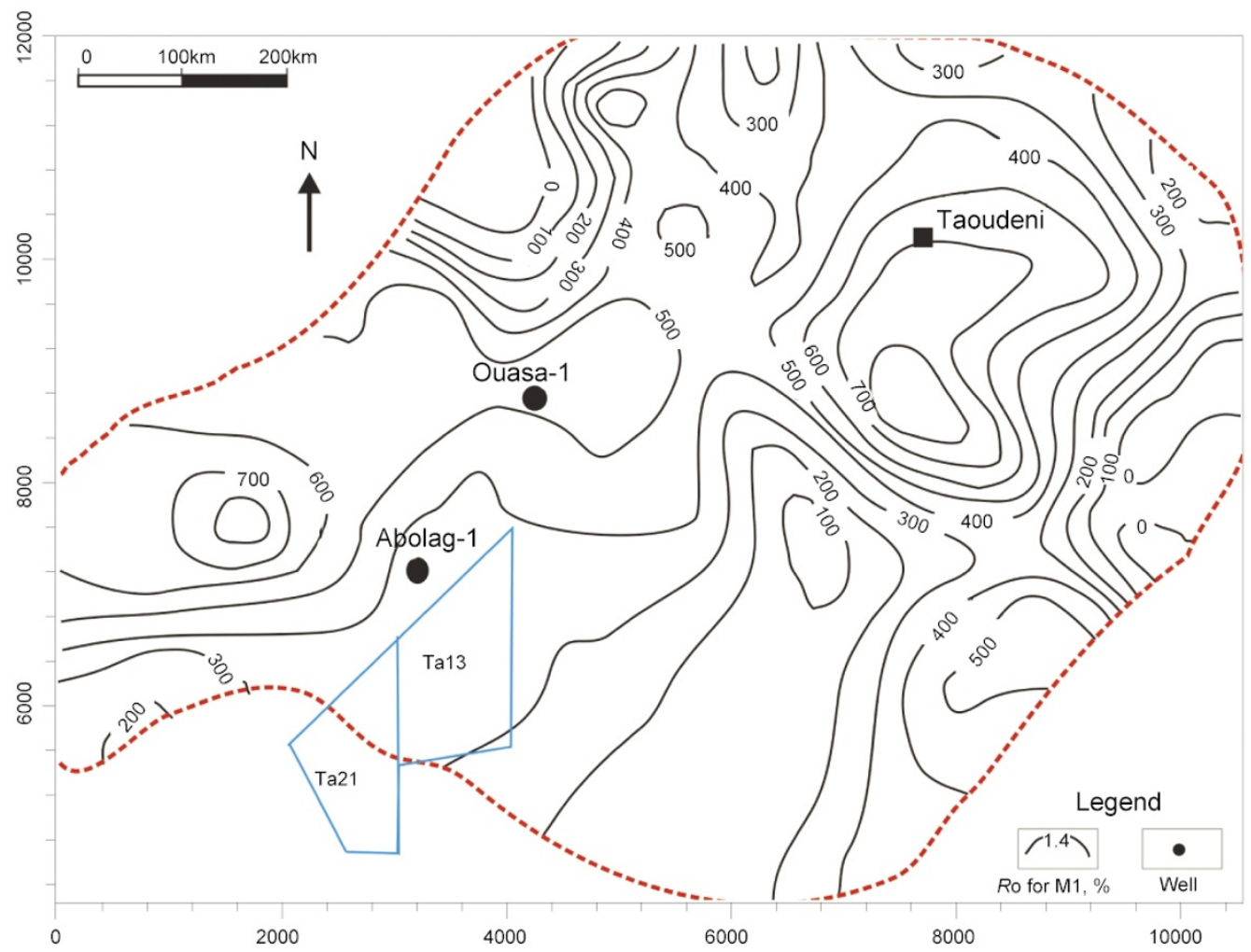

Fig. 2 Isopach map of upper Infracambrian source rocks 


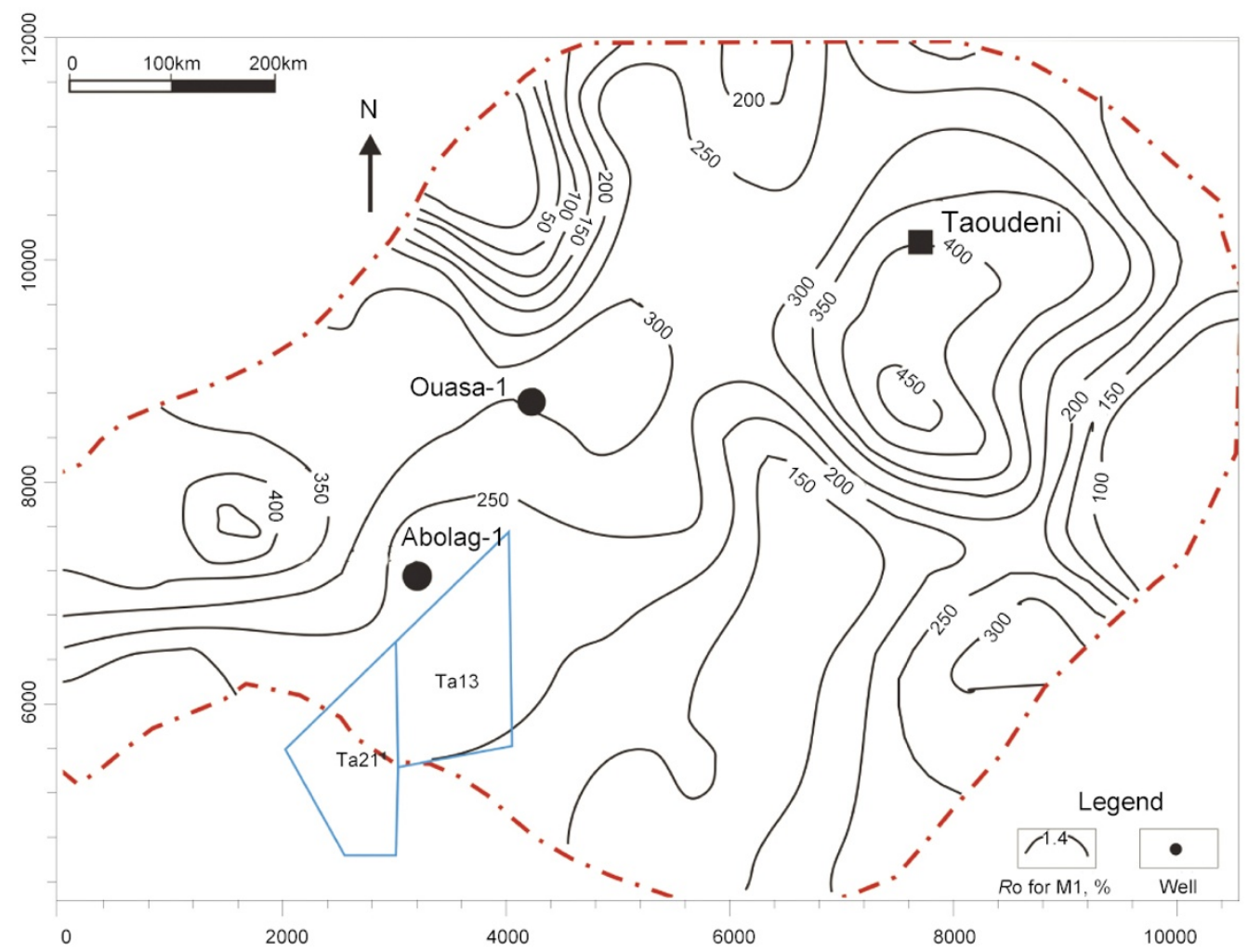

Fig. 3 Isopach map of middle Infracambrian source rocks

\section{Hydrocarbon generation and evolution history}

So as to understand the evolution and expulsion history of oil and gas in the Taoudeni Basin, we carried out basin modeling research based on the available seismic and well data. In order to study hydrocarbon generation history and oil and gas charging history, restoration of the denudation thickness is very important.

Formation denudation has developed widely in the basin. If the denudation is not significant, the influence on hydrocarbon generation, migration and accumulation may not be considerable. Otherwise, the influence will be very great, and the amount of denuded sediments needs to be restored.

\subsection{Restoration of denuded sediment thickness}

Five regional unconformable surfaces have developed in the basin. Because the data are rather limited, this study only attempts to restore the amount of the denuded sediments in the last tectonic movement, i.e., the Hercynian Orogeny. Firstly, we used seismic stratigraphic correlation in our study to divide the stratigraphic sequences, to analyze whether there was denudation and to estimate the variation pattern of relict sediments. Secondly, we used well data to determine the depositional environment in a specific area controlled by wells, and we can consider the denudation thickness at the well location or nearby as the upper and lower limit of the denudation thickness for the area around this location. At last, we obtained denudation thickness using geometry graphing and scatter calculation.

When calculating the amount of the denuded sediments for different cross sections with the above method, particular attention should be paid to the comparison of the calculated results of neighboring cross sections and intersecting cross sections. The thickness of two intersecting cross sections at the intersection point should be identical. In addition, the amount of denuded sediments for neighboring cross sections is not supposed to change too much or varies according to a particular rule governed by the basin trend and formation thickness (Fig. 4).

In Fig. $4, \Delta h$ is the original formation thickness, $\Delta h^{\prime}, \Delta h^{\prime \prime}$ and $\Delta h^{\prime \prime \prime}$ are the amounts of denuded sediments at different well points. If $\Delta h$ is known, we may approximately deduce the denudation thickness of the corresponding formation based on seismic and well data combined with the morphology of the basin. Therefore, we may restore the denudation thickness of different stratigraphic intervals with the similar method, obtain the multi-spot denudation thickness, and then draw the denudation thickness isopach map of the entire area (Fig. 5).

\subsection{Burial history}

The burial history shows that the Taoudeni Basin is a very old basin. From the Infracambrian to the present, there were a number of tectonic movements. Since the available data are limited, this study only analyzes the most significant tectonic movement. The simulated burial history of Ouasa-1 well and Abolag-1 well are illustrated in Fig. 6 and Fig. 7. The uplift associated with the Hercynian deformation event probably 


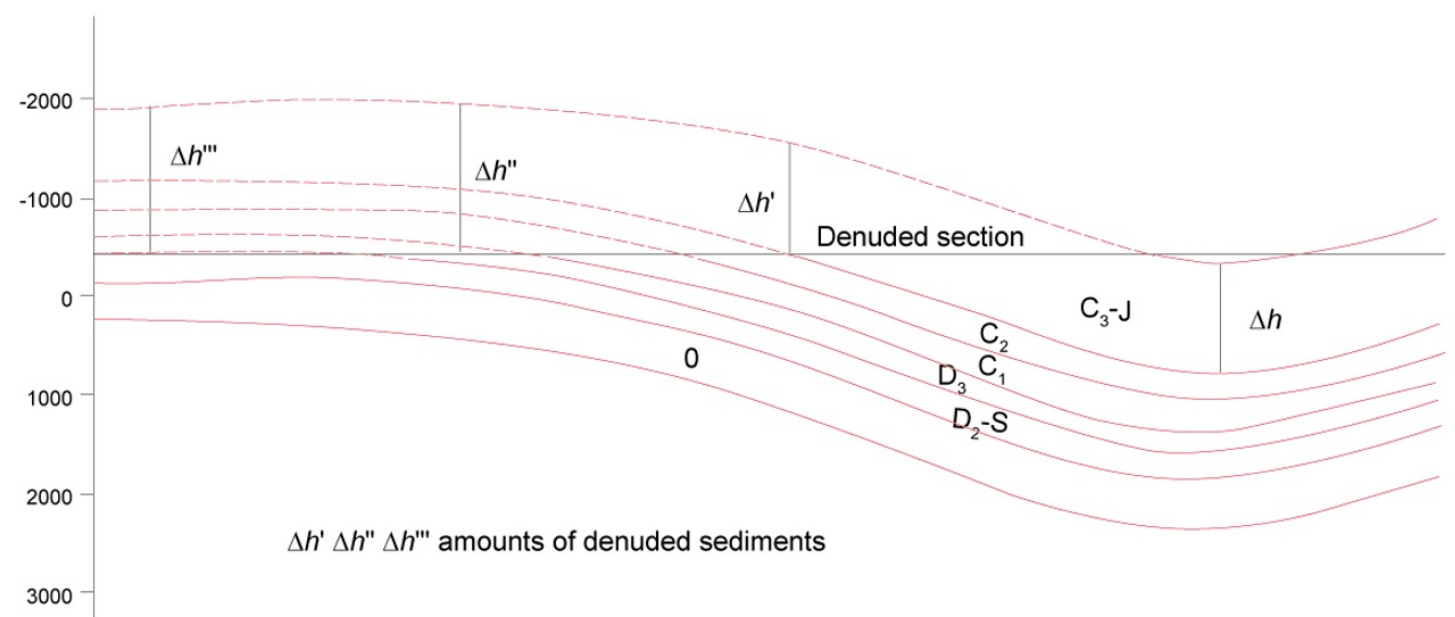

Fig. 4 Diagram showing restoration of denuded amounts of sediments

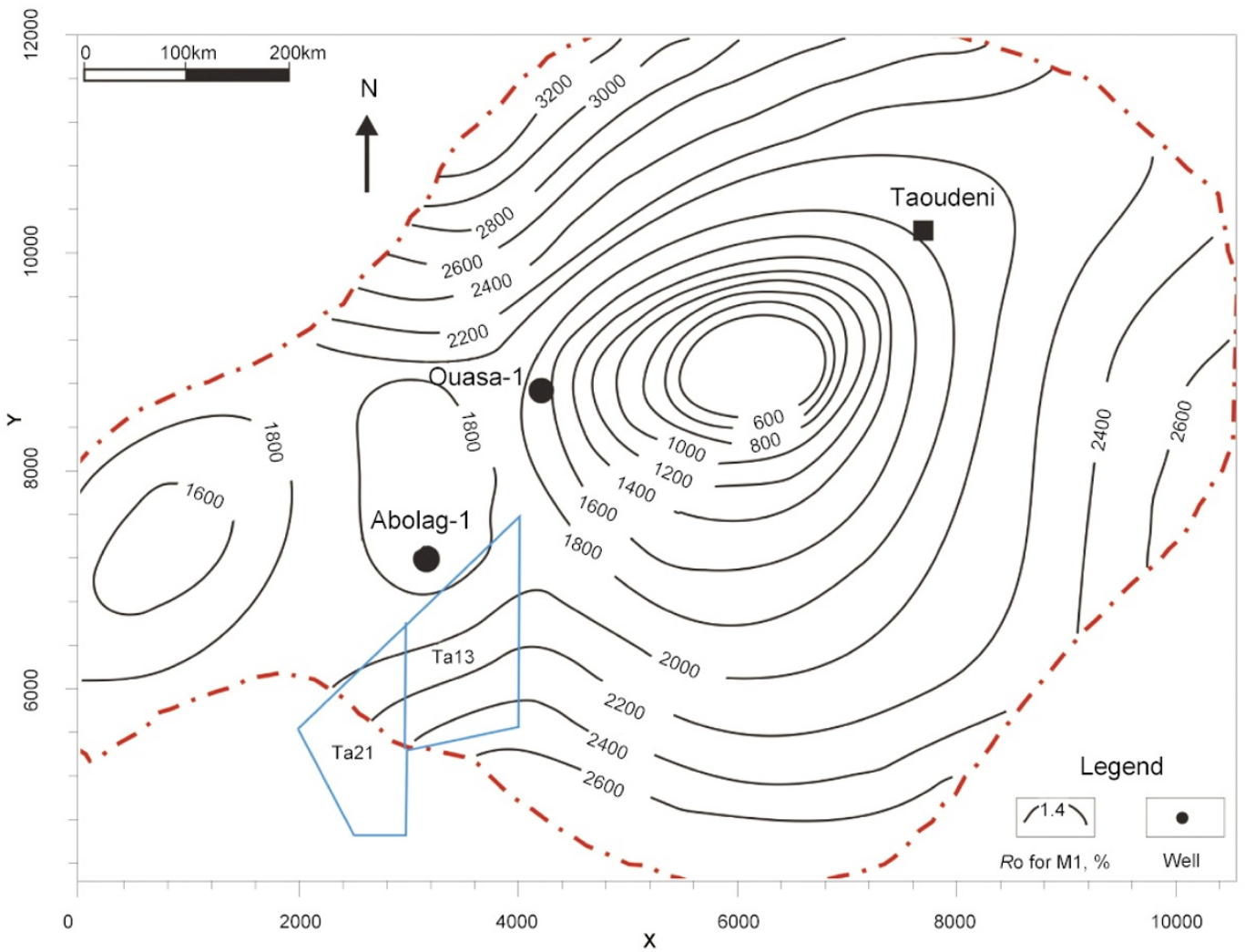

Fig. 5 Isopach map for the denuded sediments in the Taoudeni Basin

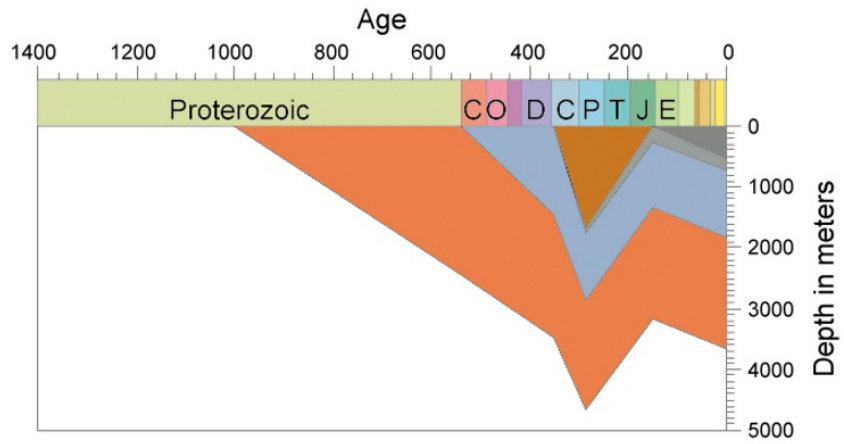

Fig. 6 Simulated burial history diagram of Ouasa-1 well

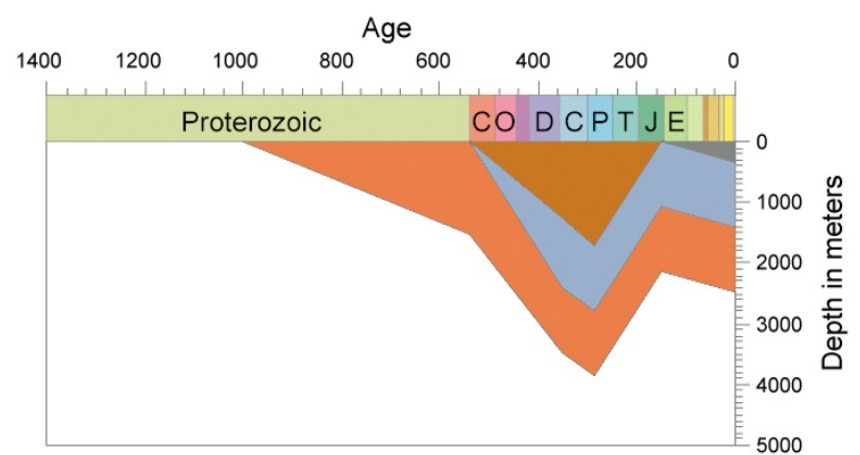

Fig. 7 Simulated burial history diagram of Abolag-1 well 
began in the late Carboniferous and led to the significant uplift and denudation of sediments (Makhous et al, 1997; Gao and Huang, 2007).

\subsection{Hydrocarbon generation history}

The evolution history of source rocks in a basin determines the period of hydrocarbon charging, and its research provides the basis for evaluation of the oil and gas resources of the basin (Huang and Gao, 2005; Liu et al, 1998). Studies on hydrocarbon generation history of the basin illustrate the process of oil and gas generation. In general, late charging and accumulation are more favorable for the formation of hydrocarbon reservoirs.

\subsubsection{Hydrocarbon generation history of Silurian source rocks}

The effective Silurian source rocks are distributed in a fairly limited area. Burial history modeling indicates that the source rocks began to generate oil at the end of the Carboniferous in the center of the depression. In other parts of the basin the source rocks are not mature (Fig. 8). As the structure uplifted and the temperature dropped, the hydrocarbon generation from the Silurian source rocks terminated.

As the two wells (Abolag-1 and Ouasa-1) are located far away from the center of the depression, Ro (vitrinite reflectance) values of the Silurian rocks of Abolag-1 and Ouasa-1 wells are less than $0.5 \%$ (Fig. 9).

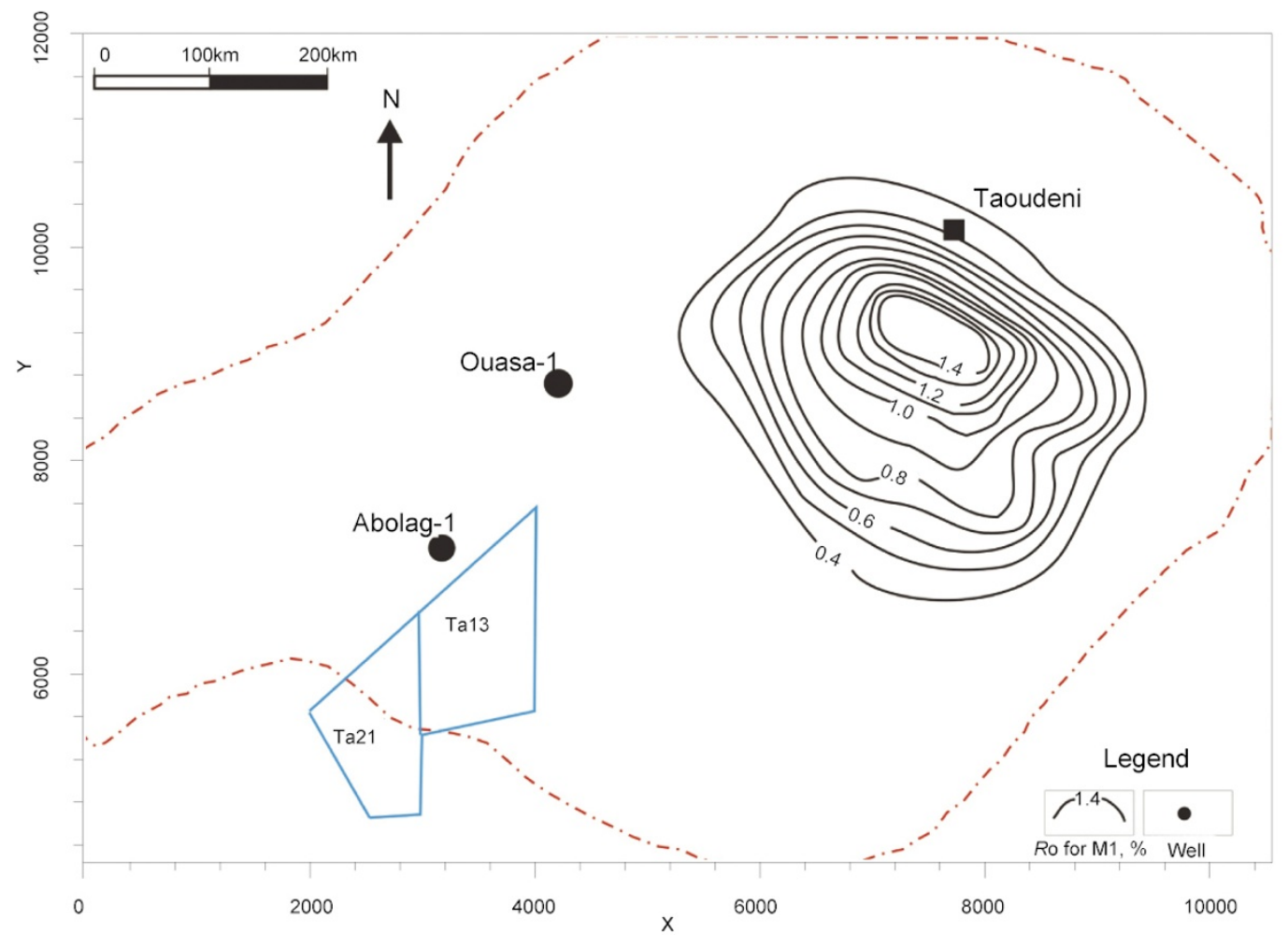

Fig. 8 Iso-Ro map of the top of the Silurian

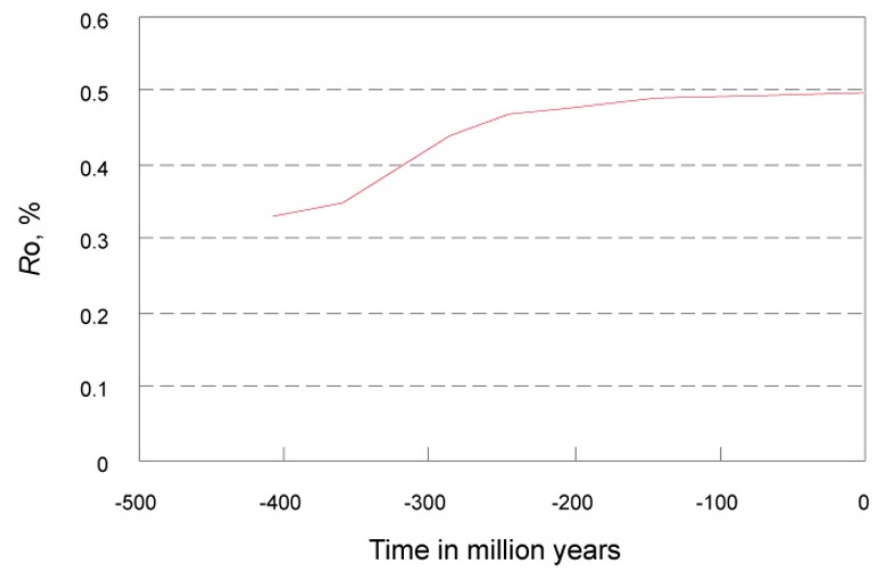

Fig. 9 Relation between $R$ o values of Silurian source rocks and time of Ouasa-1 well
4.3.2 Hydrocarbon generation history of middle Infracambrian source rocks

The Infracambrian source rocks are distributed over the entire basin and they are relatively thick. Source rocks are largely in the middle Infracambrian. The maximum value of $R o$ is over $3.6 \%$ at the base of the middle Infracambrian, over $2.6 \%$ on the top of the middle Infracambrian (Fig. 10) and more than $2.0 \%$ on the top of the upper Infracambrian.

From the generation-expulsion history curve of Infracambrian source rocks, we can know that the source rocks entered the oil-generation stage at the end of the Infracambrian and the peak oil-generation stage took place during the Ordovician-Devonian. At the end of the Carboniferous, the source rocks started to generate a great deal of gas. Consequently, the hydrocarbon generation is rather early. 


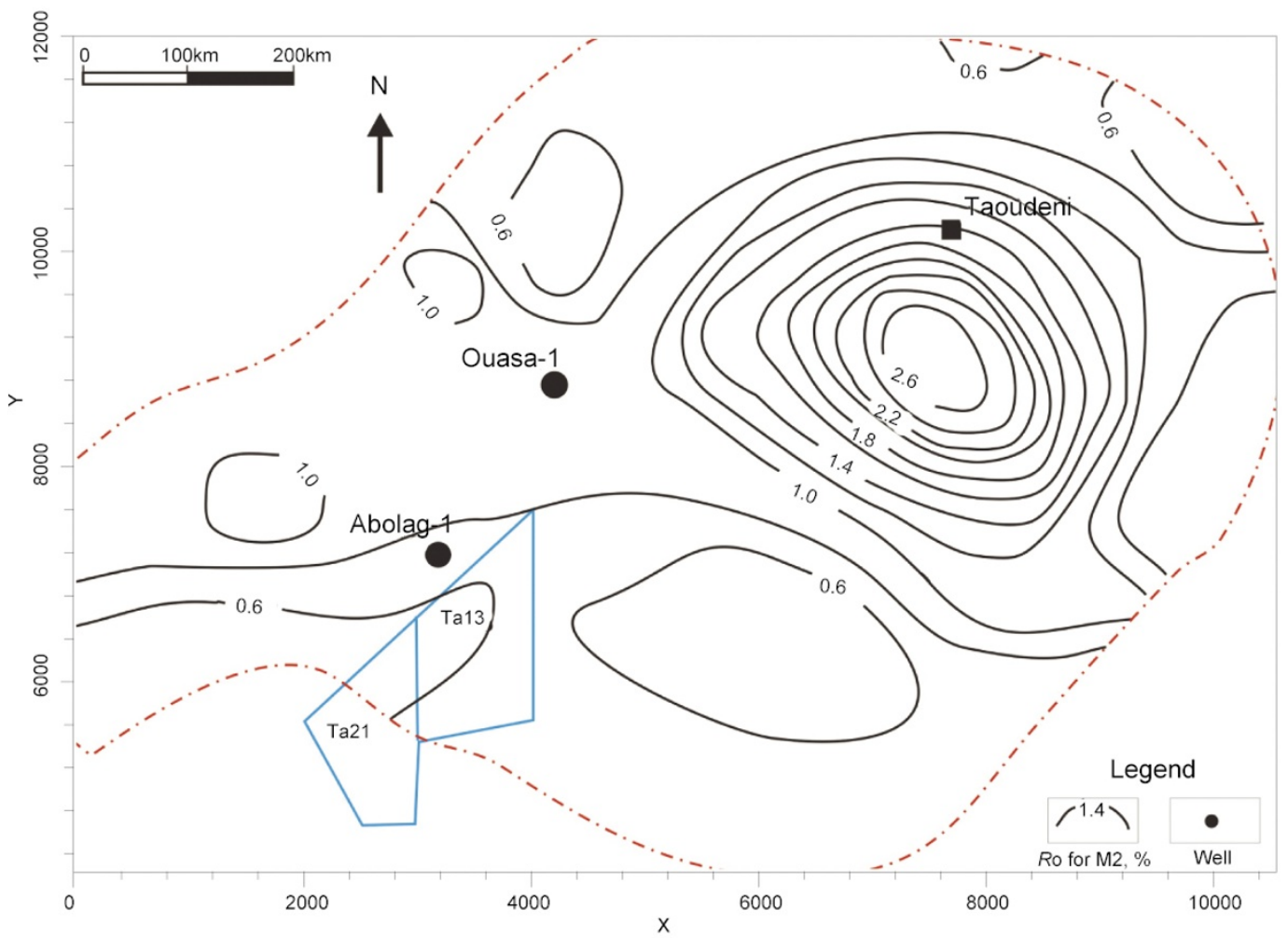

Fig. 10 Iso-Ro map at the M2 horizon

From the Ro-time relation (Fig. 11), it can be seen that the $R$ o of middle Infracambrian source rocks was about $0.7 \%$ at the end of Silurian and about $1.1 \%$ at the present. At the Ouasa-1 well location, $R$ o is about $1.18 \%$ at the present.

In summary, the hydrocarbon generation took place very early. Hydrocarbon charging occurred in the late Paleozoic. Early hydrocarbon generation and charging is unfavorable for the formation and accumulation of hydrocarbon reservoirs. In particular for a gas-generating basin, in the case of early gas generation and lack of thick plaster rock cover, the gas cannot be preserved in a great amount. Therefore, the reservoirs retaining gas are always small residual reservoirs or watersoluble gas accumulations (Klett, 2000a; 2000b).

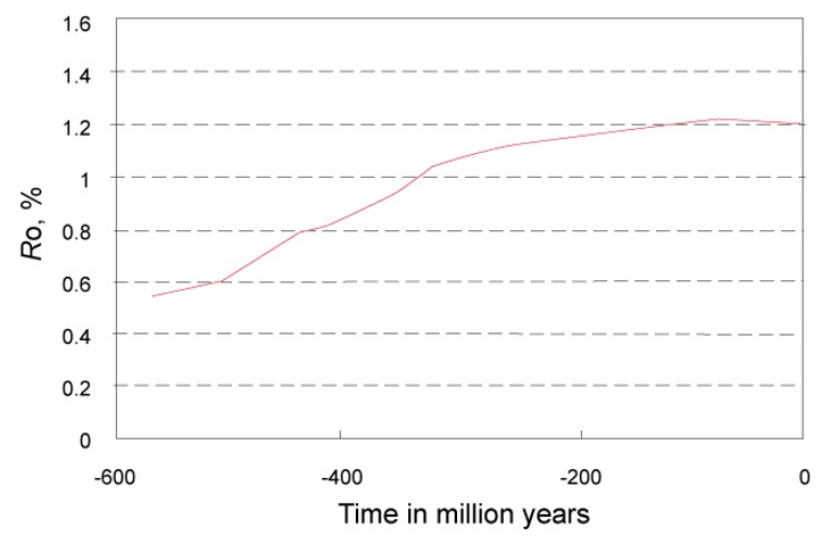

Fig. 11 Relation between $R$ o values of middle Infracambrian source rocks and time at Ouasa-1 well location

\section{Evaluation of exploration risk}

The source rocks in the study area are mainly in the middle and upper Infracambrian. There are source rocks in the Silurian, but their distribution is very limited. We studied the hydrocarbon generation and expulsion quantity of the three groups of source rocks and evaluated the source rocks.

\subsection{Hydrocarbon generation and expulsion estimates of the middle Infracambrian source rocks}

Limestones are well developed in the middle Infracambrian. We plotted the source rock isopach based on the depositional characteristics of this basin and the well data of Abolag- 1 and Ouasa-1. The maximum thickness of the source rocks reaches 450 meters and the source kitchens are located in the depressions of the basin. Considering that the middle Infracambrian is of marine origin, HI (hydrocarbon index) of $215 \mathrm{mg} / \mathrm{g}$ TOC is assigned (Fig. 12 and Fig. 13). Using a surface temperature of $25^{\circ} \mathrm{C}$ and the default temperature model, we calibrated the temperature and pressure profiles at the Quasa-1 well location.

The total amount of oil generated from the middle Infracambrian source rocks in the Taoudeni Basin is 6,791 $\times 10^{6}$ ton. The total amount of gas generated is $365,931 \times$ $10^{9} \mathrm{~m}^{3}$. The total amount of oil expelled is $2,037 \times 10^{6}$ ton and the total amount of gas expelled is $329,337 \times 10^{9} \mathrm{~m}^{3}$. The resource of oil in place is estimated to be $339 \times 10^{6}-543 \times 10^{6}$ ton. The resource of gas in place is estimated to be $731.8 \times$ $10^{9}-1,829.6 \times 10^{9} \mathrm{~m}^{3}$. The recoverable resources for oil and gas are estimated to be $76 \times 10^{6}-122 \times 10^{6}$ ton and $292.7 \times 10^{9}-731.8$ $\times 10^{9} \mathrm{~m}^{3}$ respectively. 


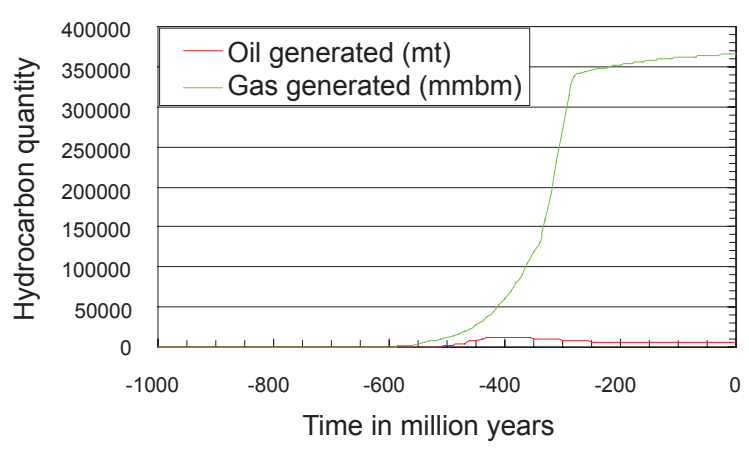

Fig. 12 Hydrocarbon generation quantity of middle Infracambrian source rocks

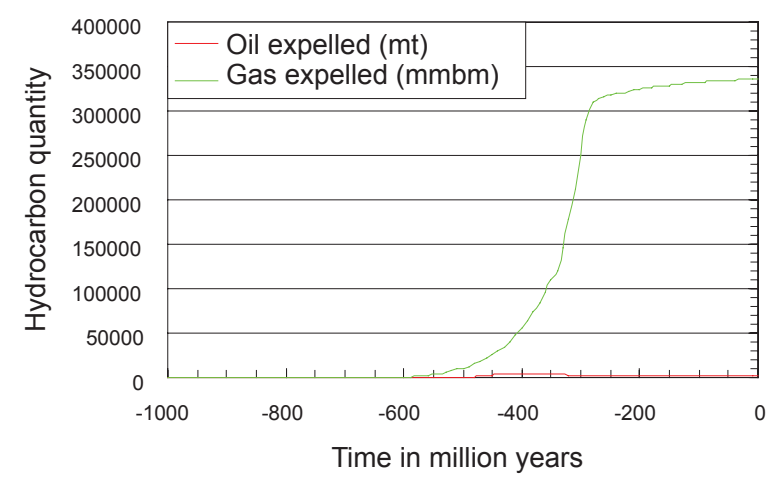

Fig. 13 Hydrocarbon expulsion quantity of middle Infracambrian source rocks

\subsection{Hydrocarbon generation and expulsion estimates of the upper Infracambrian source rocks}

The estimation principle is similar to that used for the middle Infracambrian. Based on the TOC values of upper Infracambrian source rocks from the Ouasa-1 well, we obtained TOC value by averaging the values. HI of $225 \mathrm{mg} / \mathrm{g}$ TOC was assigned (Fig. 14 and Fig. 15).

The total amount of oil generated by the upper Infracambrian source rocks in the Taoudeni Basin is $4,073 \times$ $10^{6}$ ton. The total amount of gas generated is $201,262 \times 10^{9} \mathrm{~m}^{3}$. The total amount of oil expelled is $1,222 \times 10^{6}$ ton and the total

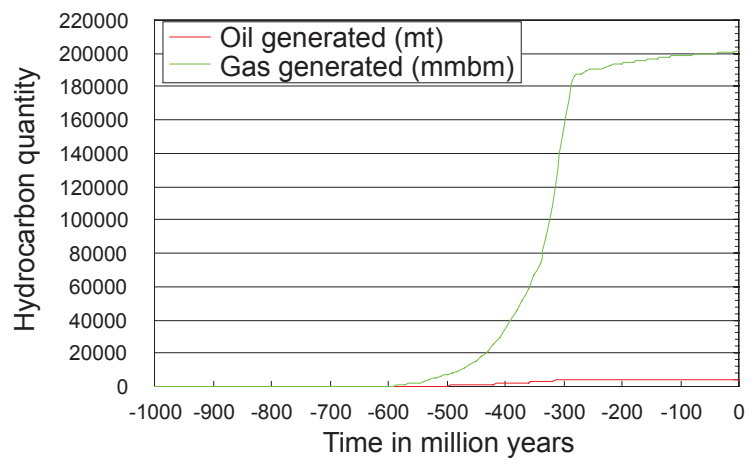

Fig. 14 Hydrocarbon generation quantity of upper Infracambrian source rocks

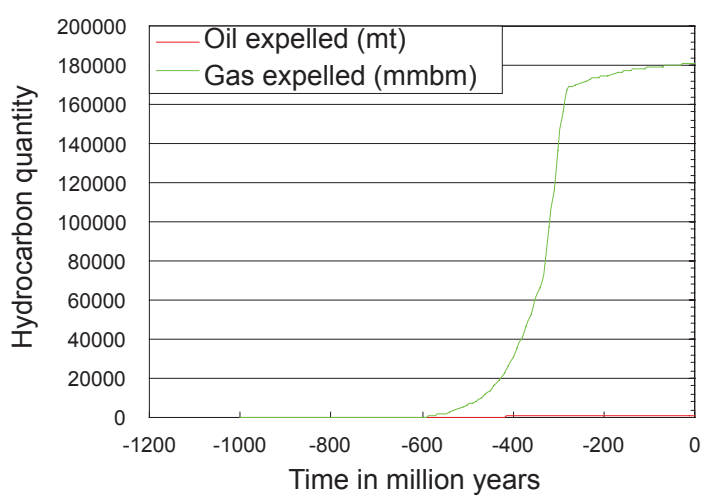

Fig. 15 Hydrocarbon expulsion quantity of upper Infracambrian source rocks

amount of gas expelled is $181,135 \times 10^{9} \mathrm{~m}^{3}$. The oil resource in place is estimated to be $204 \times 10^{6}-326 \times 10^{6}$ ton. The gas resource in place is estimated to be $402.5 \times 10^{9}-1,006.3 \times 10^{9}$ $\mathrm{m}^{3}$. The recoverable resources for oil and gas are estimated to be $46 \times 10^{6}-73 \times 10^{6}$ ton and $161 \times 10^{9}-402.5 \times 10^{9} \mathrm{~m}^{3}$ respectively.

\subsection{Generation and expulsion estimates of the Silurian source rocks}

HI was assigned based on the features of depositional facies. The simulated results are illustrated in Fig. 16 and Fig. 17.

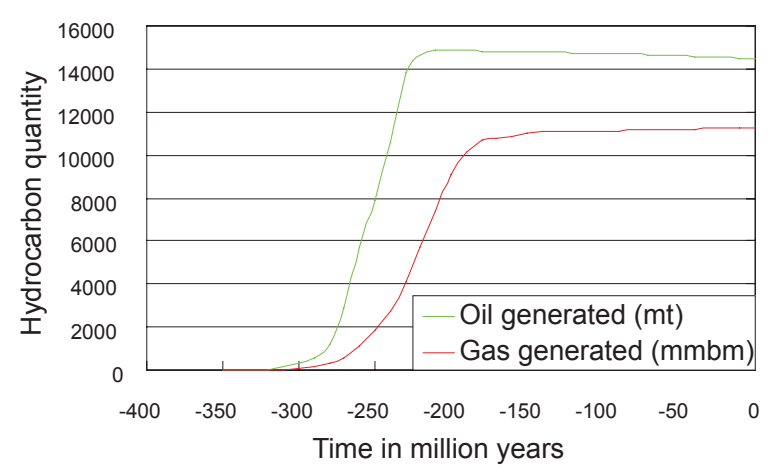

Fig. 16 Hydrocarbon generation quantity of Silurian source rocks

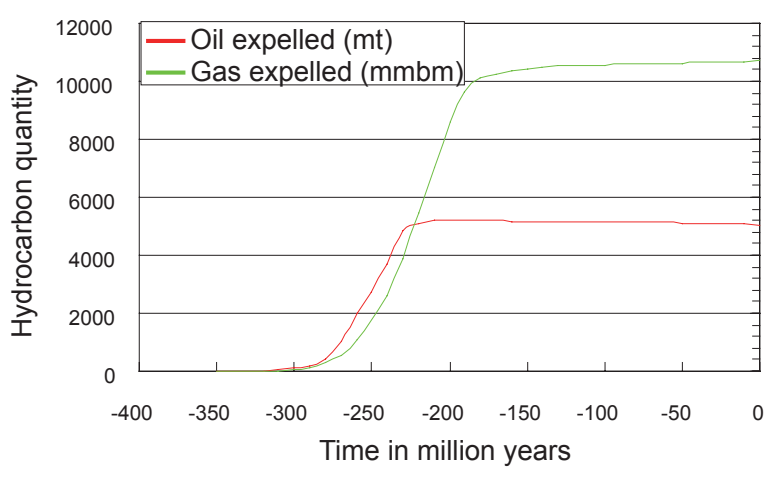

Fig. 17 Hydrocarbon expulsion quantity of Silurian source rocks 


\subsection{Total amount of hydrocarbon resources in Taoudeni Basin}

The amounts of hydrocarbon generated and expelled from different source rocks are illustrated in Fig. 18 and Fig. 19. The results are summarized in Table 2. For oil, the Silurian source rocks are the most important, whereas for gas the middle Infracambrian source rocks are the most important.

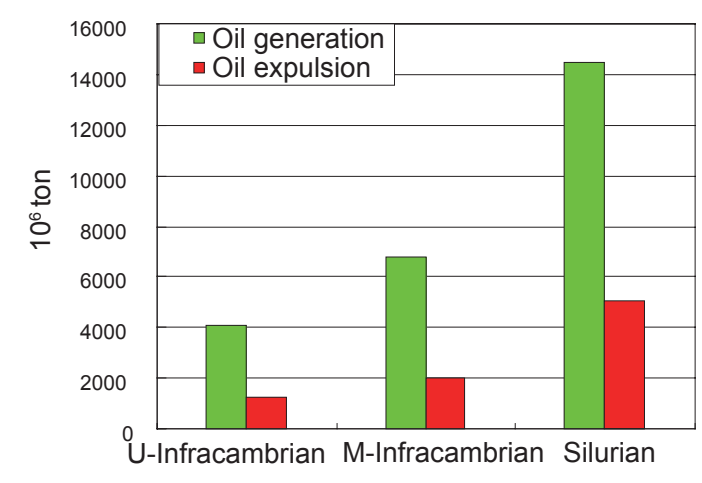

Fig. 18 Histograms for oil generated and expelled by different source rock intervals

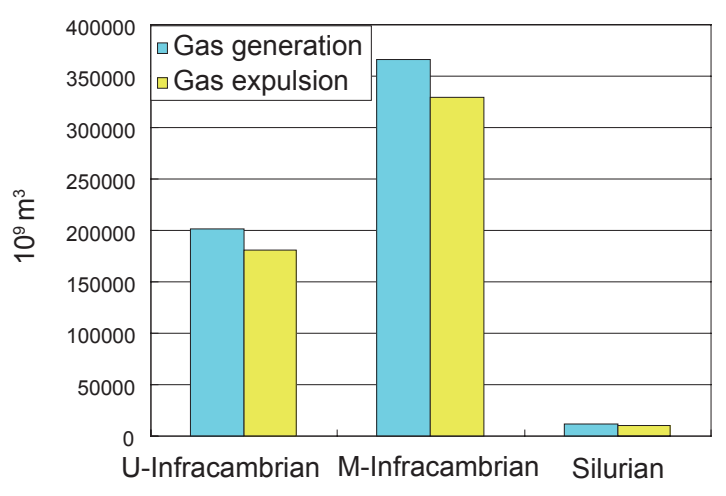

Fig. 19 Histograms for gas generated and expelled by different source rock intervals

The total oil and gas resources in place are 1,266 $\times 10^{6}-2,025 \times 10^{6}$ ton and $1,156.8 \times 10^{9}-2,892.3 \times 10^{9} \mathrm{~m}^{3}$ respectively in the Taoudeni Basin. The total recoverable resources are estimated to be $284 \times 10^{6}-456 \times 10^{6}$ ton for oil and $462.7 \times 10^{9}-1,156.9 \times 10^{9} \mathrm{~m}^{3}$ for gas respectively.

Table 2 Summary of hydrocarbon resources of Taoudeni Basin

\begin{tabular}{ccccccc}
\hline Source rock interval & Oil generated, $10^{6} \mathrm{t}$ & Oil expelled, $10^{6} \mathrm{t}$ & $\begin{array}{c}\text { Oil resource } \\
\text { in place, } 10^{6} \mathrm{t}\end{array}$ & $\begin{array}{c}\text { Gas generated, } \\
10^{9} \mathrm{~m}^{3}\end{array}$ & $\begin{array}{c}\text { Gas expelled, } \\
10^{9} \mathrm{~m}^{3}\end{array}$ & $\begin{array}{c}\text { Gas resource in place, } \\
10^{9} \mathrm{~m}^{3}\end{array}$ \\
\hline $\begin{array}{c}\text { Silurian } \\
\begin{array}{c}\text { Upper } \\
\text { Infracambrian } \\
\text { Middle } \\
\text { Infracambrian }\end{array}\end{array}$ & 14,451 & 5,058 & $723-1,156$ & 11,276 & 10,149 & $22.5-56.3$ \\
Total & $4,074.6$ & 1,222 & $204-326$ & 201,262 & $181,135.4$ & $402.5-1,006.3$ \\
\hline
\end{tabular}

\section{Conclusions}

1) The time of hydrocarbon migration and accumulation is the end of the Carboniferous, and after that, the whole basin suffered denudation for a long period.

2) There is no thick Mesozoic overburden in the basin, so the Silurian source rocks could not generate hydrocarbon in the Mesozoic era for the second time.

3) The time of gas generation in the Taoudeni Basin is too early and the basin is lack of thick plaster rock cover, so it is unlikely that a significant amount of gas has been preserved.

4) The exploration prospectivity of the Taoudeni Basin is not good.

\section{References}

Arthur T J, Macgregor D S and Cameron N R. Petroleum Geology of Africa: New Themes and Developing Technologies. London: Geological Society Pub House. 2003. Special Publication No.207: 61-84
Bennett J D, Ennih N and Toteu S F. Geological society of Africa. Episodes. 2005. 28(2): 79-96

Gao G and Huang Z L. Research advance in the history of oil pool formation. Natural Gas Geoscience. 2007. 18(5): 661-666 (in Chinese)

Huang Z L and Gao G. The natural gas origin and the model of oil-gas migration-accumulation in Moliqing Rift. Natural Gas Geoscience. 2005. 16(3): 274-276 (in Chinese)

Huang Z L, Zhong N N and Zhang S H. Comparison researches on gasgenerating rule of carbonate rocks and argillaceous source rocks. Geochimica. 2003. 32(1): 29-34 (in Chinese)

Klett T R. Total petroleum systems of the Illizi Province, Algeria and Libya-Tanezzuft-Illizi. U. S. Geological Survey Bulletin 2202-A. 2000a. 79

Klett T R. Total Petroleum Systems of the Grand Erg/Ahnet Province, Algeria and Morocco-the Tanezzuft-Timimoun, TanezzuftAhnet, Tanezzuft-Sbaa, Tanezzuft-Mouydir, Tanezzuft-Benoud and Tanezzuft-Béchar/Abadla. U. S. Geological Survey Bulletin 2202-B. $2000 \mathrm{~b}$

Liu G D, Huang Z L, Hao S S, et al. Systems and models of natural gas migration and accumulation in Tarim Basin. Acta Sedimentologica Sinica. 1998. 16(1): 58-63 (in Chinese) 
Macgregor D S, Moody R T J and Clark-Lowes D D. Petroleum Geology of North Africa. Geological Society Special Publication. 1998. 132: 7-68

Makhous M, Galushkin Y and Lopatin N. Burial history and kinetic modeling for hydrocarbon generation: part II, applying the GALO model to Saharan basins. AAPG Bulletin. 1997. 81(10): 1679-1699

Mann P, Gahagan L and Gordon M B. Tectonic setting of the world's giant oil and gas fields. In: Halbouty M T (ed.). Giant Oil and Gas Fields of the Decade 1990-1999, AAPG Memoir 78. Tulsa: AAPG. 2003. 15-105

Tong X G and Guan Z Y. Atlas of Petroleum Exploration and
Exploitation of the World (Africa Monograph). Beijing: Petroleum Industry Press. 2002. 125-131 (in Chinese)

Underdown R and Redfern J. Petroleum generation and migration in the Ghadames Basin, north Africa: A two-dimensional basin-modeling study. AAPG. 2008. 92(1): 53-76

U S Geological Survey World Petroleum Assessment 2000: Description and Results. 2000. USGS Digital Data Series-DDS-60

van de Weerd A A and Ware P L G. A review of the East Algerian Sahara oil and gas province (Triassic, Ghadames and Illizi Basins). First Break. 1994. 12(7): 363-373

(Edited by Hao Jie) 